УДК 661.12:658.628:651.31:651.32

DOI https://doi.org/10.11603/2312-0967.2020.3.11429

\title{
АНАЛІЗ АСОРТИМЕНТУ АКТИВНИХ ФАРМАЦЕВТИЧНИХ ІНГРЕДІЄНТІВ, ЗАРЕЄСТРОВАНИХ НА РИНКУ УКРАЇНИ
}

\author{
Т. А. Буткевич ${ }^{1}$ В. П. Попович ${ }^{2}$ \\ Національний медичний університет імені О. О. Богомольця ${ }^{1}$, Київ \\ TOВ «ВТФ «ЕКMІ»², Українка \\ but-t@ukr.net, valeriy.p@meta.ua
}

\section{ІНФОРМАЦІЯ}

Надійшла до редакції / Received: 02.06.2020

Після доопрацювання / Revised: 20.07.2020

Прийнято до друку / Accepted: 24.07.2020

\section{Ключові слова:}

активні фрармацевтичні інгредієнти; фрармацевтичний ринок України; асортимент.

\begin{abstract}
АНОТАЦІЯ
Мета роботи. Аналізі структурування асортиментуактивних фармацевтичних інгредієнтів (АФІ), зареєстрованих в Україні.

Матеріали і методи. Застосовано методи: контент-аналізу, структурування, порівняльного та графічного узагальнення відомостей Державного реєстру лікарських засобів та інструкцій для медичного застосування.

Результати й обговорення. На фрармацевтичному ринку України зареєстровано 2100 торгових назв АФІ, вироблених на підприємствах 51 країни. Встановлено, що частка вітчизняного виробництва складає дещо більше $16 \%$, з них 1/5 виготовлено на базі ПрАТ «Ліктрави» (лікарська рослинна сировина). 3-поміж іноземних переважають виробники Індії (29,1 \%), серед яких лідерами є Гетеро Драгз Лімітед (5,9 \%) та Гетеро Лабз Лімітед (5,5 \%).

3-поміж проаналізованих стратегічно важливих зареєстрованих лікарських засобів українського виробництва (засобів, що впливають на систему крові на гемопоез (групи В01, В02, В05 згідно з АТС-класифрікацією), препаратів гормонів для системного застосування (групи Н01, Н02), протимікробних засобів для системного застосування (групи J01, J02, J04)) виявлено відсутність вітчизняних АФІ.

Висновки. В результаті аналізу асортименту зареєстрованих АФІ встановлено перевагу іноземних синтетичних номенклатурних позицій (71,4 \%). Серед вітчизняних АФІ переважають рослинні (55,8 \%), з яких майже половина $(44,4 \%) \in$ лікарською рослинною сировиною. Частка українських АФІ у складі окремих досліджених груп лікарських засобів $€$ надзвичайно малою, що зумовлює необхідність термінових заходів для налагодження та оптимізації виробництва тих АФІ, які є складовими стратегічно важливих груп лікарських засобів.
\end{abstract}

Вступ. Розробка та впровадження у виробництво (екстемпоральне і промислове) оригінальних лікарських засобів (ЛЗ) є довготривалими та дороговартісними, потребують значних фрінансових та інтелектуальних інвестицій на кожному з етапів життєвого циклу ЛЗ (синтез хімічних речовин, вирощування лікар- ської рослинної сировини (ЛРС), мікробіологічне культивування продуктів біотехнології тощо, а також подальші фрармакологічні, фрармако-технологічні, аналітичні та інші дослідження). На жаль, сьогодні виробництво ЛЗ в Україні значно залежить від імпорту сировини $[1,2]$, оскільки співвідношення зареє-

ISSN 2312-0967. Pharmaceutical review. 2020. № 3 
Фармацевтичний менеджмент, маркетинг та логістика Pharmaceutical management, marketing and logistics

строваних активних фрармацевтичних інгредієнтів (АФІ) вітчизняного та іноземного виробництва складає 1 до 5,2.

У своїх роботах Г. В. Костюк, А. В. Коваленко, О.В.Доровський, В. М. Кушнірук, А. В. Вітюк, К. Р. Траченко та ін. розглянули окремі питання розвитку світового та українського ринків АФІ, частково вказали на аспекти, пов'язані із станом їхнього виробництва [3-6], але здійснений аналіз джерел інформації доводить відсутність досліджень 3 аналізу вітчизняного ринку.

Мета роботи - аналіз і структурування асортименту АФІ, зареєстрованих в Україні.

Матеріали і методи. У роботі застосовано методи: контент-аналізу, структурування, порівняльного та графрічного узагальнення відомостей Державного реєстру Лз та інструкцій для медичного застосування ЛЗ.

Результати й обговорення. Відповідно до даних Державного реєстру ЛЗ станом на 21.04.2020 року в Україні зареєстровано 2100 торгових назв (ТН) АФІ: синтетичних речовин, напівпродуктів, ЛРС та ін., використання яких дозволено при виготовленні ЛЗ в Україні [2]. Частка вироблених на вітчизняних підприємствах становить дещо більше 16 \% від вказаної кількості.

В Україні зареєстровано 1761 ТН АФІ іноземного виробництва 351 країни, серед яких частка АФІ виробників 3 Індії переважає - 512 ТН (29,1 \% від загальної частки зарубіжних виробників), Китаю $486 \mathrm{TH}(27,7 \%)$, Італії - 156 TH (8,9\%), Іспанії 121 TH (6,9 \%) та Німеччини - 110 ТН (6,3 \%) (рис. 1). Країни-виробники, частка АФІ яких на ринку менша, було поділено на 2 умовні групи: ті, кількість зареєстрованих АФІ яких становить 11-47 ТН (Франція $47 \mathrm{TH}$, Японія - $37 \mathrm{TH}$, Швейцарія - 29 ТН, Чеська
Республіка - 25 ТН, Російська Федерація - 24 ТН, Польща - 19 ТН, Корея - 17 ТН, Аргентина, Мексика, Нідерланди та США - по 12 TH, Грузія та Єгипет - по $11 \mathrm{TH)} \mathrm{й} \mathrm{ті,} \mathrm{кількість} \mathrm{зареєстрованих} \mathrm{АФІ} \mathrm{яких} \mathrm{стано-}$ вить менше 10 TH (31 країна).

Спільне виробництво іноземних АФІ виявлено у випадку 35 ТН АФІ (для 33 ТН виробництво здійснюється двома підприємствами-виробниками), виготовлення двох найменувань відбувається на трьох фрармацевтичних підприємствах: «Парікальцитолу» на Дішман Нейдерландс Б.В., Нідерланди / Проксі Лабораторіс Б.В., Нідерланди / Карбоген АМЦІС АГ, Швейцарія (власником реєстраційного посвідчення на АФІ $€$ ТОВ «Артеріум Лтд», Україна); «Цинхокаїну гідрохлориду» на Фармасинтез, Франція / Мікро-Масіназйоне С.А., Швейцарія / Лаб-Сервіс С.А., Франція (власником реєстраційного посвідчення на АФІ $€$ ТОВ «ТК «Аврора», Україна).

Вітчизняний фрармацевтичний ринок наповнений АФІ індійського походження - 512 ТН постачають 179 індійських підприємств, з яких 85 виготовляють по одній ТН. У п'ятірку лідерів підприємств-виробників входять Гетеро Драгз Лімітед (30 ТН, що становить 5,9 \% від загальної частки), Гетеро Лабз Лімітед - 28 ТН (5,5 \%), Аарті Драгз Лімітед, Іпка Лабораторіз Лімітед та Нош Лабз Прайвет Лімітед - по 16 ТН (по 3,1 \% відповідно).

Встановлено, що 334 ТН вітчизняних АФІ виготовлено 44 українськими виробниками. Лідерами є:

- ПрАТ «Ліктрави» - 68 ТН (20,4%) ЛРС, яка зареєстрована як АФІ;

- ТОВ «Фармацевтична компанія «Здоров'я» 34 TH (10,2 \%);

- ПАТ «Галичфрарм» - 30 ТН $(9,0 \%) ;$

- ТОВ «Фармхім» - 27 ТН (8,1\%);

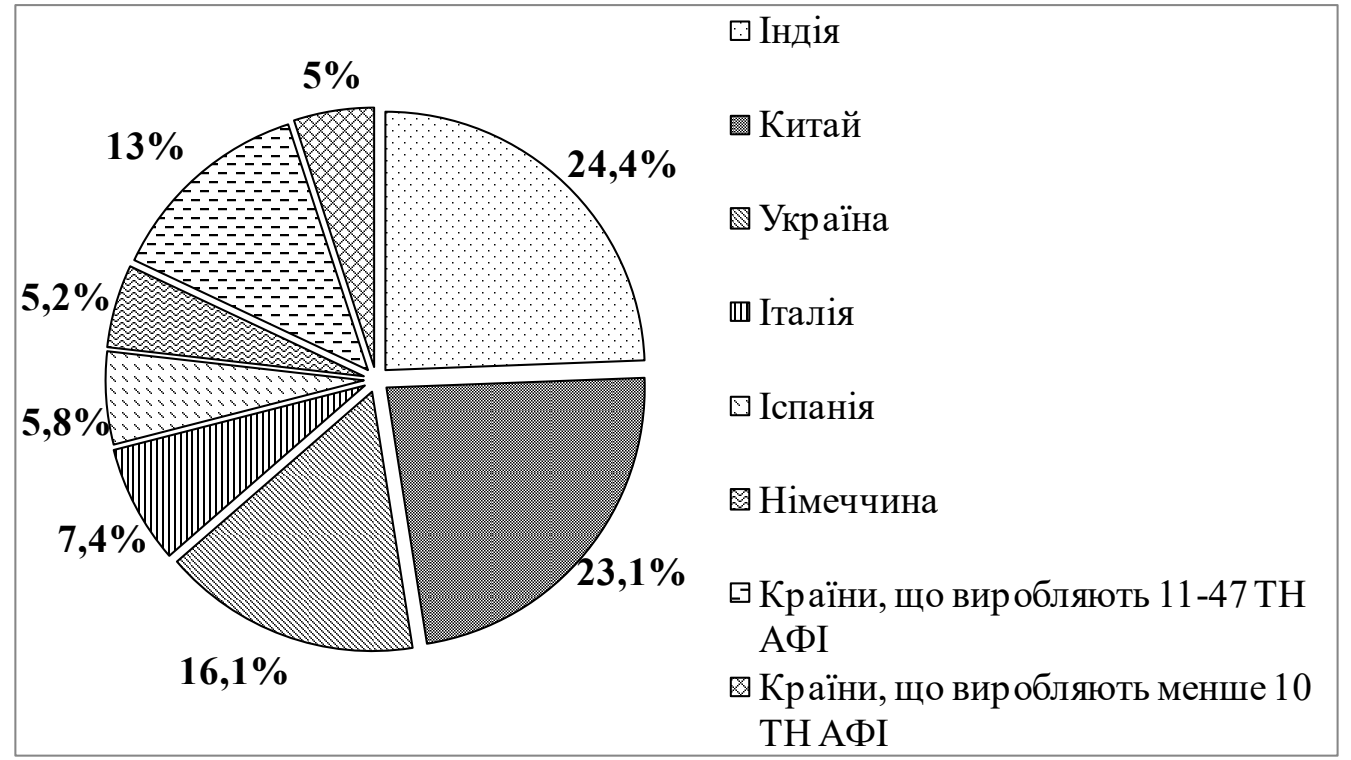

Рис. 1. Розподіл АФІ зареєстрованих в Україні за країнами-виробниками.

ISSN 2312-0967. Фармацевтичний часопис. 2020. № 3 
Фармацевтичний менеджмент, маркетинг та логістика

Pharmaceutical management, marketing and logistics

- ПАТ «Науково-виробничий центр «Борщагівський хіміко-орармацевтичний завод» - 23 ТН (6,9\%).

Продуктами спільного виробництва вітчизняних та зарубіжних компаній 5 ТН АФІ є:

- «Мебгідролін» виготовлено на ПАТ «Фармак» (стадія очистки субстанції) та ТОВ «Цзіаньська медико-хімічна компанія Хайчжоу», Китай (виробник сировини);

- «Докузат натрію 85 \%» виготовлено на ТДВ «Інтерхім» (випуск серії) та Лахачем органікс Прайвет Лімітед, Індія (виробництво за повним циклом, крім випуску серії);

- «6-метилурацил» виготовлено на ТОВ «Фармхім» (доочищення, сушіння, пакування, випуск серії) та Хай Хоуп Інт'л Груп Цзянсу Медісінес енд Хелз Продуктс Імпорт енд Експорт Корпорейшн Лімітед, Китай (повний цикл виробництва, крім випуску серії);

- «Фенспіриду гідрохлорид» виготовлено на ТОВ «Фармхім» (доочищення, сушіння, пакування, випуск серії) та Хангджоу Чемтех Індустрі Корпорейшн Лімітед, Китай (виробництво технічного (неочищеного) продукту);

- «Сорбітол» виготовлено на ТОВ «Істок-Плюс» (вторинне пакування (маркування), контроль якості, випуск серії) та Каргіл Дойчланд ГмбХ, Німеччина (виробництво, первинне пакування, вторинне пакування, контроль якості).

Власниками реєстраційного посвідчення на АФІ $€$ 245 заявників із 24 країн (рис. 2). Серед іноземних переважають заявники з Індії - 112 ТН, що становить 5,3 \% від загальної кількості, Іспанії - 55 TH (2,6 \%), Китаю, Німеччини та Хорватії - 44, 43 та 43 ТН відповідно (по 2,1 \%). Визначено трійку підприємств Індії, серед 112 суб'єктів підприємницької діяльності, якими подано найбільшу кількість заявок для отримання реєстраційного посвідчення на АФІ власного виробництва: Гетеро Драгз Лімітед - 28 ТН, що становить 25,0 \% від загальної кількості, Гетеро Лабз Лімітед 25 TH (22,3 \%), Нош Лабз Прайвет Лімітед - 16 ТН $(14,3$ \%). Варто зазначити, що ТОВ «Фармацевтична компанія «Здоров'я» $є$ заявником 2 ТН АФІ виробництва Гетеро Драгз Лімітед та однієї ТН - Гетеро Лабз Лімітед. ТОВ «Харківське фрармацевтичне підприємство «Здоров'я народу» $є$ заявником 1 ТН АФІ виробництва Гетеро Лабз Лімітед.

Власниками реєстраційних посвідчень на 1670 ТН АФІ (79,5 \%) як вітчизняного, так й іноземного виробництва, є 100 українських суб'єктів підприємницької діяльності. Лідерами серед них $є$ :

- ТОВ «Фармацевтична компанія «Здоров'я» 232 ТН, що становить 13,9 \%;

- ПАТ «Фармак» - 154 ТН (9,2 \%);

- ПрАТ «Фармацевтична фрірма «Дарниця» - 95 ТН $(5,7 \%)$

- АТ «Київський Вітамінний Завод» - 90 ТН (5,4 \%);

- ТОВ «Торгова компанія «Аврора» - 83 ТН (5,0 \%).

Аналіз дозволених для виробництва в Україні АФІ за природою / походженням показав, що зареєстровано: 1644 ТН синтетичних АФІ (78,3 \% від загальної кількості зареєстрованих), 363 ТН рослинних АФІ $(17,3 \%)$ та 93 ТН біологічного походження АФІ (4,4 \%) (рис. 3). ЛРС займає значну частку серед вітчизняних АФІ (84 ТН / 44,4 \%) та незначну 3-поміж АФІ іноземного виробництва (34 ТН / 19,5\%).

105 ТН АФІ рослинного походження (за винятком ЛРС) вироблено такими українських виробникам:

- ТОВ «Фармацевтична компанія «Здоров'я» (27 TH);

- ПАТ «Галичфрарм» (26 ТН);

- ПАТ «Науково-виробничий центр «Борщагівський хіміко-фрармацевтичний завод» (14 ТН);

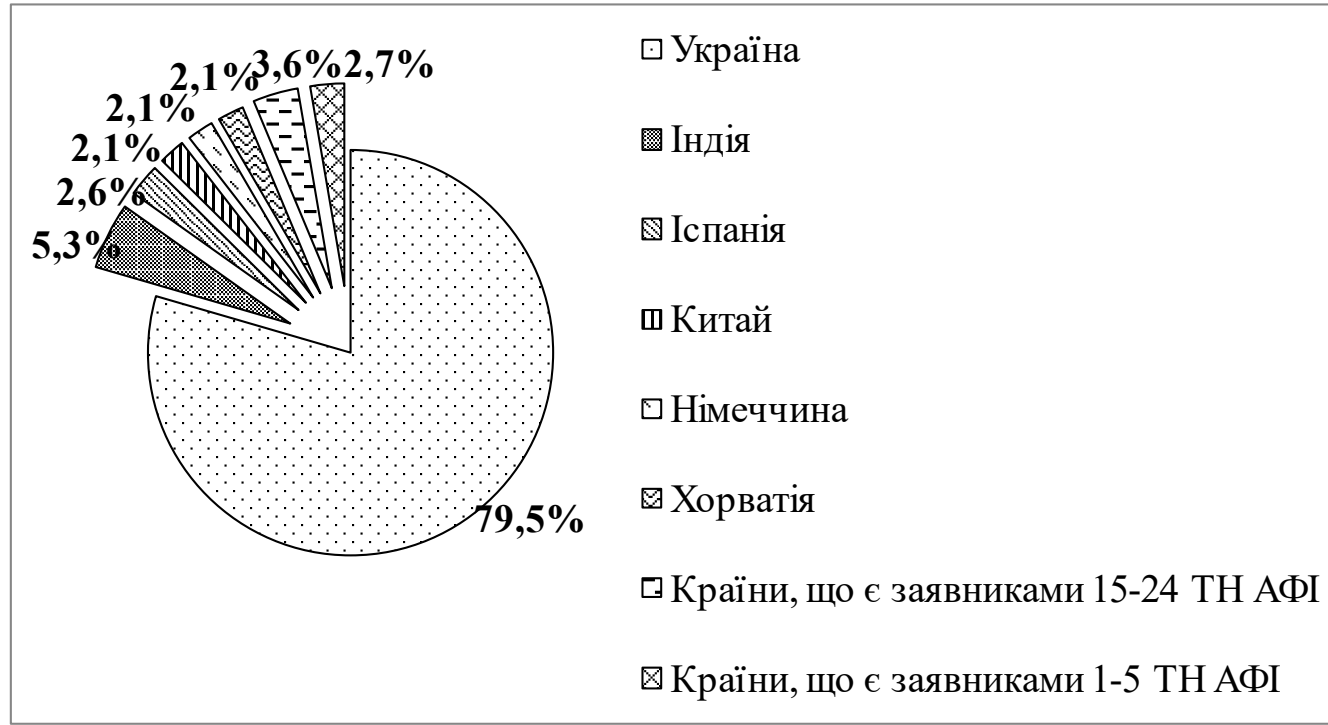

Рис. 2. Розподіл АФІ зареєстрованих в Україні за країнами-заявниками.

ISSN 2312-0967. Pharmaceutical review. 2020. № 3 
Фармацевтичний менеджмент, маркетинг та логістика

Pharmaceutical management, marketing and logistics

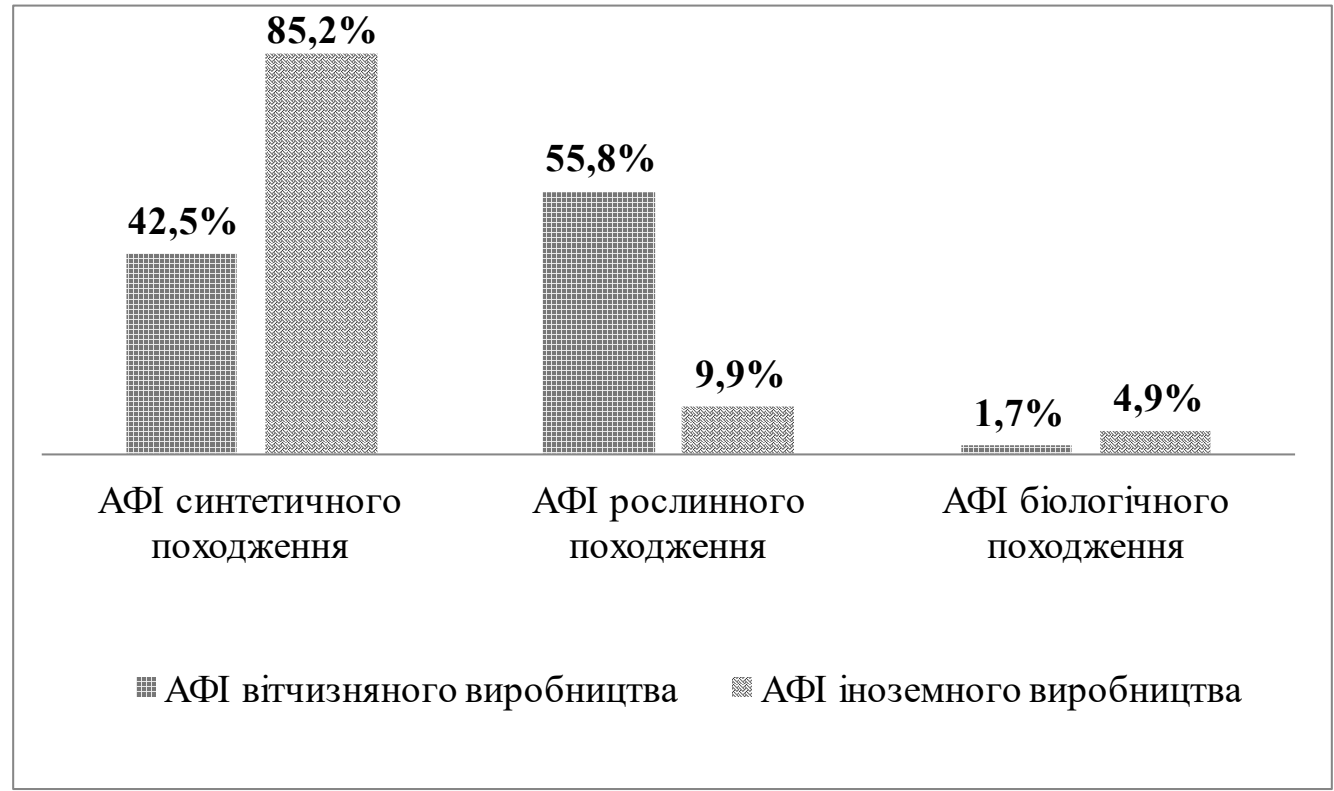

Рис. 3. Розподіл АФІ зареєстрованих в Україні за природою / походженням.

- АТ «Фармак» та ПАТ «Хімсрармзавод «Червона зірка» (по $8 \mathrm{TH})$;

- ТОВ «Дослідний завод «ГНЦЛС», ТОВ «Науково-виробнича компанія «Екофрарм» та ТОВ «Тернофрарм» (по $3 \mathrm{TH})$;

- ПАТ «Фармак», ПрАТ «Біолік», ТОВ «Наукововиробнича фрармацевтична компанія «Ейм» та ТОВ «Сінбіас Фарма» (по 2 ТН);

- ДП «Експериментальний завод медичних препаратів Інституту біоорганічної хімії та нафтохімії Національної академії наук України», ДП «Завод хімічних реактивів Науково-технологічного комплексу «Інститут монокристалів» Національної академії наук України», ПАТ «Вітаміни», ТОВ «Виробниче об'єднання «Тетерів» та ТОВ «Фармхім» (по 1 ТН).

Було встановлено, що значну частку серед номенклатурних позицій цієї групи АФІ займають: екстракти 3 ЛРС сухі - 18 ТН, що становить 17,1 \% від загальної частки вітчизняних рослинних АФІ, рідкі - 15 ТН $(14,3 \%)$, густі - 10 ТН (9,5\%) та настойки - 8 ТН (7,6\%).

Визначено, що зареєстровані в Україні АФІ представлено: у твердих формах (порошки, гранули, пелети, екстракти сухі, ЛРС) 1933 ТН, з яких 254 ТН є вітчизняного виробництва; рідких (суспензії, рідини, розчини, олії, настойки, екстракти рідкі та густі) - $159 \mathrm{TH}, 3$ яких $80 €$ вітчизняного виробництва; м'яких (гелі, м'які маслянисті маси, воскоподібні маси) - $8 \mathrm{TH}$, з яких 4 ТН вітчизняного виробництва.

Проведений аналіз дозволяє зробити висновок про значне домінування на ринку України АФІ іноземного виробництва, 3 яких частка синтетичних складає 71,4 \% від усіх зареєстрованих ТН, тоді як серед вітчизняних АФІ значно представлені ЛРС та екстрактами, отриманими на її основі.

Однією з цілей довгострокової стратегії розвитку фрармацевтичної галузі є виробництво АФІ для досягнення максимального рівня виготовлення усіх необхідних вітчизняних лз різної направленості терапевтичної дії [1]. 3 огляду на результати здійсненого аналізу та враховуючи сучасні ризики, пов'язані із проведенням Операції об'єднаних сил, пандемією Covid-19 (закриття кордонів, встановлення економічних перепон тощо), вказана ціль набуває особливої актуальності і значущості.

Одними із стратегічно важливих груп лз згідно 3 АТС-класифрікацією є: В01 (антитромботичні засоби), В02 (антигеморагічні засоби), В05 (кровозамінники та перфузійні розчини), Н01 (гіпофрізарні, гіпоталамічні гормони та їхні аналоги), Н02 (кортикостероїди для системного застосування), J01 (антибактеріальні засоби для системного застосування), J02 (протигрибкові засоби для системного застосування), J04 (засоби, що діють на мікобактерії) та інші ЛЗ.

Відповідно до даних Державного реєстру та інструкцій для медичного застосування ЛЗ визначено:

- 3-поміж 101 ТН зареєстрованих Л3 групи В01 (антитромботичні засоби) $33 \mathrm{TH} є$ вітчизняного виробництва, вони містять 6 ТН АФІ (зареєстровано 17 номенклатурних позицій), що вироблено на підприємствах Індії (52,9 \%), Китаю (35,3 \%), Італії та Таїланду (по 5,9 \%);

- зареєстровано 46 ТН групи Л3 В02 (антигеморагічні засоби), із них 26 ТН українського виробництва, у складі яких 4 ТН АФІ (10 номенклатурних позицій). Виробниками цих АФІ є підприємства Китаю (40,0 \%), України (20,0%), Іспанії, Індії, Польщі та Японії (по

ISSN 2312-0967. Фармацевтичний часопис. 2020. № 3 
10,0 \%). ДП «Завод хімічних реактивів Науково-технологічного комплексу «Інститут монокристалів» Національної академії наук України» (Україна) та ДП «Науково-дослідний і проектний інститут хімічних технологій «Хімтехнологія» (Україна) є виробниками по одному АФІ «Амінокапронова кислота»;

- до групи ЛЗ В05А (кров та споріднені препарати) належать 13 вітчизняних ТН, що становить майже половину зареєстрованих в Україні ЛЗ цієї групи (27 ТН Л3). Їхніми складовими є 2 ТН АФІ (7 номенклатурних позицій), що виробляють підприємства Китаю (57,1%), Австрії, Данії та Німеччини (по 14,3 \%).

- групу Л3 В05В (розчини для внутрішньовенного введення) представлено 64 TH (39 ТН вітчизняного виробництва), групу Л3 В05С (ірригаційні розчини) 12 ТН (10 ТН вітчизняного виробництва), групу Л3 B05D (засоби для перитонеального діалізу) - $20 \mathrm{TH}$ (9 ТН вітчизняного виробництва), групу Л3 В05Х (додаткові розчини для внутрішньовенного введення) 54 ТН (49 ТН вітчизняного виробництва), групу Л3 B05Z (гемодіалітики та гемофрільтрати) - 3 ТН. Українські Л3 цих груп включають 27 ТН АФІ (64 номенклатурні позиції), що вироблено у 13 країнах світу. Лідерами 3-поміж виробників є Японія (28,1\%), Німеччина (26,6 \%) та Чеська Республіка (10,9 \%). «Аргініну глутамат» (2 номенклатурні позиції) виготовляє ТОВ «Фармацевтична компанія «Здоров'я» (Україна), «Гліцин» (одна номенклатурна позиція) - ТОВ «Фармхім» (Україна), «Сорбітол» (одна номенклатурна позиція) - спільне виробництво підприємств України (ТОВ «Істок-Плюс») та Німеччини (Каргіл Дойчланд ГмбХ);

- зареєстровано 41 ТН (6 ТН вітчизняного виробництва) групи Л3 Н01 (гіпофрізарні, гіпоталамічні гормони та їхні аналоги). Вітчизняні ЛЗ містять 3 ТН АФІ (6 номенклатурних позицій), які виробляють на підприємствах Іспанії (50,0 \%), США (33,3 \%) та Китаю $(16,7 \%)$

- групу лз Н02 (кортикостероїди для системного застосування) складають 53 ТН, 3-поміж них 19 ТН вітчизняного виробництва, до складу яких входять 8 ТН АФІ (22 номенклатурні позиції). Лідерами 3-поміж виробників є підприємства Іспанії $(36,4 \%)$, Китаю $(27,3 \%)$ та Малайзії (13,6 \%);

- 3-поміж 946 ТН Л3 групи J01 (антибактеріальні засоби для системного застосування) 276 ТН є українського виробництва. До їхнього складу входять 63 ТН АФІ (169 номенклатурних позицій). Ці АФІ виготовлено у 11 країнах, домінують виробники Китаю (55,6 \%), Індії $(20,1 \%)$ та Іспанії (11,2\%). «Діоксидин» (одна номенклатурна позиція) та «Стрептоцид розчинний» (2 номенклатурні позиції) виробляє ТОВ «Фармхім» (Україна);

- групу Л3 02 (протигрибкові засоби для системного застосування) представлено зареєстрованими 119 ТН, 43 ТН з яких вітчизняного виробництва. Українські ЛЗ цієї групи містять 3 ТН АФІ (11 номенклатур- них позицій), які виготовлено у Індії (90,9%) та Іспанії $(9,1 \%)$;

- зареєстровано 57 ТН ЛЗ групи J04 (засоби, що діють на мікобактерії), з них 26 ТН виробляють в Україні з використанням 10 ТН АФІ (22 номенклатурні позиції), що виготовлено у 6 країнах. 3-поміж виробників домінують підприємства Китаю (40,9 \%) та Індії (22,7 \%). Одну номенклатурну позицію «Натрію аміносаліцилат дигідрат» виготовляє ТОВ «Фармхім» (Україна).

Результати аналізу Л3, що входять до складу окремих груп життєво необхідних, дозволяють простежити наявність на ринку України вітчизняних виробників цих ЛЗ, подекуди у більшості, або принаймні у кількості від 20 до 50 \% від зареєстрованих ТН. Проте складовими аналізованих ЛЗ українського виробництва $€$ іноземні АФІ практично у всіх групах. Частка вітчизняних АФІ $€$ надзвичайно малою, а саме у 8 групах досліджуваних стратегічно важливих ЛЗ АФІ вітчизняного виробництва складають у сумі 6 ТН (9 номенклатурних позицій) та 1 ТН спільного виробництва українського та іноземного підприємств. Лише один АФІ - «Натрію аміносаліцилат дигідрат» (виробництва ТОВ «Фармхім», Україна) може бути складовою ЛЗ, що входить до Національного переліку основних ЛЗ [8].

На сьогодні термінове вжиття усіх необхідних заходів для налагодження та оптимізації вітчизняного виробництва АФІ, які $є$ складовими стратегічно важливих груп Л3, має стати одним із першочергових завдань державної політики.

Відповідно, пошук нових джерел біологічно активних речовин синтетичного, рослинного і біологічного походження, синтез хімічних сполук, їхнє всебічне вивчення стають ще актуальнішими завданнями фрармацевтичної науки.

Висновки. За результатами аналізу даних Державного реєстру ЛЗ України станом на 21.04.2020 року встановлено, що в Україні:

- зареєстровано 2100 ТН АФІ із 51 країни світу, 3 них 339 ТН є АФІ вітчизняного виробництва;

- 1500 ТН (85,2 \%) АФІ іноземного виробництва $€$ синтетичними засобами;

- вітчизняне виробництво АФІ переважно представлене засобами рослинного походження - 55,8 \% (189 ТН), з яких ЛРС складає 44,4 \% (84 ТН).

у більшості проаналізованих зареєстрованих лз українського виробництва (груп В01, В02, В05, Н01, H02, J01, J02, J04 згідно АТС класифікації) виявлено відсутність вітчизняних АФІ.

Налагодження та оптимізація вітчизняного виробництва АФІ, які є складовими стратегічно важливих груп ЛЗ, має стати одним із першочергових завдань державної політики.

Конфлікт інтересів: відсутній.

Conflicts of interest: authors have no conflict of interest to declare.

ISSN 2312-0967. Pharmaceutical review. 2020. № 3 
Фармацевтичний менеджмент, маркетинг та логістика

Pharmaceutical management, marketing and logistics

\title{
ANALYSIS OF THE ACTIVE PHARMACEUTICAL INGREDIENTS ASSORTMENT REGISTERED ON UKRAINE MARKET
}

\author{
T. A. Butkevych ${ }^{1}$, V. P. Popovych ${ }^{2}$ \\ O. Bohomolets National Medical University ${ }^{1}$, Kyiv \\ PTF "Acme" Co. Ltd", Ukrainka \\ but-t@ukr.net,valeriy.p@meta.ua
}

The aim of the work. To analyze and structure the active pharmaceutical ingredients assortment registered on Ukraine market.

Materials and Methods. The content analysis, structuring, comparative and graphical generalization of data from the State Register of Medicines and pharmaceutical inserts were applied.

Results and Discussion. 2100 trade names of active pharmaceutical ingredients, that are manufactured in 51 countries, are registered on Ukraine pharmaceutical market. It is established that the level of domestic ones is over $16 \%, 1 / 5$ of their total number is manufactured by JSC "Liktravy" (medicinal plant raw materials). Indian companies predominate among foreign manufacturers (29.1\%). Hetero Drugs Limited (5.9 \%) and Hetero Labs Limited (5.5 \%) companies are leaders.

The absence of domestic active pharmaceutical ingredients in the composition of analyzed strategically important registered drugs of Ukrainian production (blood and blood forming organs (groups B01, B02, B05 according to the ATC classification), systemic hormonal preparations (groups H01, H02), anti-infectives for systemic use (groups J01, J02, J04)) was revealed.

Conclusions. The advantage of foreign synthetic active pharmaceutical ingredients with the share of $71.4 \%$ is noted according to the results of registered on market of Ukraine active pharmaceutical ingredients assortment analysis. Plant trade names (55.8\%), predominate among the domestic active pharmaceutical ingredients, almost half of them (44.4\%) are medicinal plant raw materials. The share of Ukrainian active pharmaceutical ingredients in the composition of studied groups of drugs is extremely small. Taking urgent measures for adjustment and optimization of production of active pharmaceutical ingredients that are components of strategically important groups of drugs, is necessary.

ey words: active pharmaceutical ingredients; pharmaceutical market of Ukraine; assortment (range, value).

\section{АНАЛИЗ АССОРТИМЕНТА АКТИВНЫХ ФАРМАЦЕВТИЧЕСКИХ ИНГРЕДИЕНТОВ, ЗАРЕГИСТРИРОВАННЫХ НА РЫНКЕ УКРАИНЫ}

\author{
Т. А. Буткевич ${ }^{1}$, В. П. Попович ${ }^{2}$ \\ Национальный медицинский университет имени А. А. Богомольца ${ }^{1}$, Киев \\ ООО «ПТФ «ЭКМИ» 2, Украинка \\ but-t@ukr.net, valeriy.p@meta.ua
}

Цель работы. Провести анализ и структурирование ассортимента активных фрармацевтических ингредиентов, зарегистрированных на рынке Украины.

Материалы и методы. Применены методы: контент-анализа, структурирования, сравнительного и грасического обобщения сведений Государственного реестра лекарственных средств и инструкций по применению.

Результаты и обсуждение. На фрармацевтическом рынке Украины зарегистрировано 2100 торговых наименований активных фрармацевтических ингредиентов, которые произведены на предприятиях 51 страны. Установлено, что доля отечественного производства составляет немного больше $16 \%$ из них 1/5 изготовлено на базе 3АО «Лектравы» (лекарственное растительное сырье). Среди иностранных производителей преобладают предприятия Индии (29,1 \%), лидирующие позиции принадлежат Гетеро Драгз Лимитед (5,9%) и Гетеро Лабз Лимитед (5,5 \%). В большинстве проанализированных стратегически важных зарегистрированных лекарственных средств украинского производства (средств, влияющих на систему крови на гемопоэз (группы В01, В02, В05 согласно АТСклассификации), препаратов гормонов для системного применения (группы Н01, Н02), противомикробных средств для системного применения (группы J01, J02, J04)) отсутствуют отечественные активные фрармацевтические ингредиенты.

Выводы. По результатам анализа ассортимента зарегистрированных активных фармацевтических ингредиентов отмечено преимущество иностранных синтетических номенклатурных позиций (71,4 \%). Среди отечественных активных фрармацевтических ингредиентов преобладают растительные $(55,8$ \%), из которых почти половина (44,4 \%) является лекарственным растительным сырьем. Доля украинских активных фрармацевтических ингредиентов в составе отдельных исследованных групп лекарственных средств являются чрезвычайно малой, что вызывает необходимость срочного

ISSN 2312-0967. Фармацевтичний часопис. 2020. № 3 
принятия мер по налаживанию и оптимизации производства тех активных фрармацевтических ингредиентов, которые являются составными стратегически важных групп лекарственных средств.

Ключевые слова: активные фрармацевтические ингредиенты; фрармацевтический рынок Украины; ассортимент.

\section{Список бібліографічних посилань}

1. Доровський О. В., Олійник А. Д. Фармацевтична промисловість України: сучасний стан та напрями стратегічного розвитку. Науковий вісник Херсонського державного університету. Сер. : Економічні науки. 2014. Вип. 7(4). С. 75-8.

2. Державний реєстр лікарських засобів України. URL: http://www.drlz.com.ua.

3. Костюк Г. В., Коваленко А. В. Конкурентоспроможність фрармацевтичної промисловості України. Ефрективна економіка. 2013. № 11. URL: http://www. economy.nayka.com.ua/?op=1\&z=2547.

4. Доровський О. В. Світовий фрармацевтичний ринок: структура, тенденції розвитку, точки зростання. Науковий вісник Херсонського державного університету. Сер. : Економічні науки. 2014. Вип. 9 (1). С. 34-8.
5. Кушнірук В. М. Стандартизація промислового синтезу активних фрармацевтичних інгредієнтів на прикладі амізону та дибамку : автореф. дис. на здобуття наук. ступеня канд. фрармац. наук : 15.00.03. X., 2017. C. 3.

6. Вітюк А. В., Траченко К. Р. Суперечливі тенденції розвитку фрармацевтичної промисловості України. Вісник Вінницького політехнічного інституту. Сер. : Економіка та менеджмент. 2018. № 6. C. $35-43$.

7. Деякі питання державного регулювання цін на лікарські засоби і вироби медичного призначення : Постанова Кабінету Міністрів України від 25.03.2009 № 333 (зі змінами). URL: https://zakon.rada.gov.ua/ laws/show/333-2009-\%D0\%BF\#n15

\section{References}

1. Dorovskiy OV, Oliynyk AD. [Pharmaceutical industry of Ukraine: current status and directions of strategic development]. Naukovyi visnyk Khersonskoho derzhavnoho universytetu. Seria: Ekonomichni nauky. 2014;7(4): 75-8. Ukrainian.

2. State Register of Medicines of Ukraine [Electronic resource]. Available from: http://www.drlz.kiev.ua.

3. Kostiuk HV, Kovalenko AV. [Competitiveness of the pharmaceutical industry of Ukraine]. Efektyvna ekonomika. 2013; 11. Available from: http://www.economy. nayka.com.ua/?op=1\&z=2547. Ukrainian.

4. Dorovskiy OV. [World pharmaceutical market: structure, development trends, growth points]. Naukovyi visnyk Khersonskoho derzhavnoho universytetu. Seria: Ekonomichni nauky. 2014;9(1): 34-8. Ukrainian.

5. Kushniruk VM. [Standardization of industrial synthesis of active pharmaceutical ingredients by the example of amizone and dibamk]. Extended abstract of Candidate's thesis.15.00.03. Kharkiv; 2017. Ukrainian.

6. Vitiuk AV, Trachenko KR. [Supplementary trends in development of the pharmaceutical industry of Ukraine]. Visnyk Vinnytskoho politekhnichnoho instytutu. Seriia: Ekonomika ta menedzhment. 2018;6: 35-43. DOI: https://doi.org/10.31649/1997-9266-2018-141-6-3543. Ukrainian.

7. Some issues of state regulation of prices for medicines and medical devices: resolution of the Cabinet of Ministers of Ukraine March 25, 2009 No. 333. [Electronic resource]. Available from: https://zakon.rada.gov.ua/ laws/show/333-2009-\%D0\%BF\#n15.

\section{Відомості про авторів}

Буткевич Т. А. - магістр фрармац., асист. кафредри аптечної та промислової технології ліків, Національний медичний університет імені О. О. Богомольця, Київ, Україна. E-mail: but-t@ukr.net, ORCID 0000-0002-7570-6150. mailto:OFBLSERG@gmail.com

Попович В. П. - д. фрармац. наук, доцент, головний технолог ТОВ «ВТФ «ЕКМІ», Українка, Україна. E-mail: valeriy.p@ meta.ua, ORCID 0000-0001-7164-539X.

\section{Information about the authors}

Butkevych T. A. - Master (Pharmacy), assistant of the Pharmaceutical and Industrial Technology of Medicines Department, O. O. Bohomolets National Medical University, Kyiv, Ukraine. E-mail: but-t@ukr.net, ORCID 0000-0002-7570-6150. mailto:OFBLSERG@gmail.com

Popovych V. P. - DSc (Pharmacy), Associate Professor, main technologist of "PTF "Acme" Co. Ltd, Ukrainka, Ukraine. E-mail: valeriy.p@meta.ua, ORCID 0000-0001-7164-539X.

ISSN 2312-0967. Pharmaceutical review. 2020. № 3 